\title{
DIAGNOSTIC VALUE OF THE CHARACTERISTICS OF STAPHYLOCOCCUS HYICUS AND STAPHYLOCOCCUS CHROMO- GENES
}

\author{
B. SKALKA
}

Department of Microbiology and Immunology, University of Veterinary Science, 61242 Brno

Received Fanuary 22, 1991

\begin{abstract}
Skalka B.: Diagnostic Value of the Characteristics of Staphylococcus hyicus and Staphylococcus chromogenes. Acta vet. Brno, 60, 1991: 277-283.

The value of the following 12 characteristics of Staphylococcus hyicus and Staphylococcus chromogenes for their routine identification was assessed: inhibition of staphylococcal delta haemolysin, hyaluronidase production, Tween 80 hydrolysis, proteolytic, phosphatase and urease activity, pigment production and aerobic acid production from sucrose, trehalose, mannose, maltose and mannitol. Of a total of 937 novobiocin-sensitive staphylococci use in the study 544 were $S$. hyicus strains, 322 were $S$. chromogenes strains and 71 showed characteristics classifying them as intermediaries between the two species. The characteristic shared by all of them was their ability to inhibit staphylococcal delta haemolysin. All $S$. hyicus strains produced hyaluronidase and hydrolysed Tween 80 . On the basis of their differing proteolytic activity and carbohydrate utilization they were divided into three groups unequal in number. All $S$. chromogenes strains were intensely proteolytic, did not produce hyaluronidase and did not hydrolyse Tween 80 . On the basis of their differing pigment production and acid production from carbohydrates they were divided into three groups unequal in number. The 71 strains originally not classified within either of the two species hydrolysed Tween 80 . In view of this characteristic they were classified by us within the species $S$. hyicus although they did not produce hyaluronidase.
\end{abstract}

Staphylococcus hyicus, Staphylococcus chromogenes, inhibition of delta haemolysin, hyaluronidase, hydrolysis of Tween 80 , proteolysis, phosphatase, urease, pigment, sucrose, trehalose, mannose, maltose, mannitol

Since 1986 (Kloss and Schleifer 1986; Hájek et al. 1986) Staphylococcus hyicus and Staphylococcus chromogenes have enlarged the number of coagulase-positive and coagulase-negative staphylococcal species which can be very often encountered upon routine examination of materials particularly of animal provenience (Skalka 1990b). The identification of the two species is complicated by the possibility of their being taken for other staphylococci as has been pointed out by a number of writers cited in our previous study (Skalka 1988a) and by further investigators (Gahrn-Hansen et al. 1987; Geary et al. 1989). Our previous studies on $S$. hyicus and $S$. chromogenes strains were concerned not only with the generally accepted characteristics of the two species (Skalka 1988a; 1990b) but also with the detection and description of some additional activities shared by these two species, namely their haemolytic activity (Skalka 1988b) and their ability to inhibit the haemolytic effect of staphylococcal delta haemolysin (Skalka 1990a; 1991). The present study on $S$. hyicus and $S$. chromogenes is focused on their major characteristics detectable in the laboratory with respect to their diagnostic value.

Materials and Methods

Nutrient Media

The bases used for liquid nutrient media were Sugar Fermentation Series Base No. 2 (IMUNA, Czechoslovakia) and Nutrient Broth (OXOID) and those used for solid media were Blood Agar 
Base No. 4 (IMUNA, Czechoslovakia) and Blood Agar Base (OXOID). For determination of the charácteristics under study the afore-mentioned based were supplemented with respective ingredients.

\section{Bacterial Strains}

A total of 937 novobiocin-sensitive staphylococci were examined. Of these, $544(58 \%)$ were $S$. hyicus strains including culture collection strains CCM 2368, CNCTC M 51/88, CNCTC M $52 / 88$ and CNCTC $M$ 69/89, and $322(34.4 . \%)$ were $S$. chromogenes strains including culture collection strains CCM 3387, CNCTC $M$ 45/88, CNCTC $M$ 46/88 and CNCTC $M$ 47/88. The remaining $71(7.6 \%)$ strains with characteristics classifying them as intermediaries between the two species were tentatively referred to as Group "X". All the 937 strains were isolated during a 5-year period from pigs, cattle and domestic fowls kept on 35 different farms.

Characteristics Examined

Each strain was examined for the following 12 characteristics: ability to inhibit staphylococcal delta haemolysin, hyaluronidase activity, lipolytic activity (hydrolysis of Tween 80 ), proteolytic activity, phosphatase activity, urease activity, pigment production and ability to produce acid from sucrose, trehalose, mannose, maltose and mannitol under aerobic conditions. The techniques of the tests were described in detail previously (Skalka $1977 ; 1988 \mathrm{a} ; 1$ 1990a; 1990b; 1991).

\section{Results}

All S. hyicus strains inhibited staphylococcal delta haemolysin, produced hyaluronidase, hydrolysed Tween 80 and did not produce pigment. On the basis of their further characteristics they were divided into three groups designated as $\mathrm{A}, \mathrm{B}$ and $\mathrm{C}$.

Group A included $281(51.6 \%$ ) strains that were proteolytic, produced acid from sucrose and trehalose but not from mannitol. Phosphatase was produced by $98.9 \%$, urease by $77.9 \%$ and acid from mannose and maltose by $66.2 \%$ and $25.6 \%$ of Group A strains, respectively. Group B included 187 (34.4\%) strains. None of them was proteolytic, which was a marked difference from the strains of the preceding group. Similarly to Group A strains, Group B strains all produced acid from sucrose and trehalose. Phosphatase and urease were produced by $93.6 \%$ and $93 \%$ of the strains, respectively. Acid from mannose, maltose and mannitol was produced by $69.5 \%, 34.8 \%$ and $5.9 \%$ of Group B strains, respectively. The least numerous Group C included $76(14 \%)$ strains that differed from the preceding two groups by their inactivity in carbohydrates, particularly in sucrose and trehalose. Phosphatase was produced by $96 \%$, proteolytic activity was shown by $55.3 \%$, whereas urease was produced by as few as $6.6 \%$ of Group C strains.

The properties shared by all $S$. chromogenes strains were inhibition of staphylococcal delta haemolysin, markedly intense proteolysis, lack of hyaluronidase activity and inability to hydrolyse Tween 80 . On the basis of their further characteristics $S$. chromogenes strains were divided into three groups designated as I, II and III.

Group I included $66(20.5 \%)$ strains that were markedly chromogenic and produced acid from sucrose. Phosphatase activity was shown by $94 \%$, hydrolysis of urea by $88 \%$ and production of acid from trehalose also by $88 \%$ of the strains. Acid from mannose, maltose and mannitol was produced by $68 \%, 38 \%$ and $18 \%$ of Group I strains, respectively. Group II including $219(68 \%)$ strains differed from Group I by lack of pigmentation and by production of acid from both sucrose and trehalose. Phosphatase activity was shown by $91 \%$ and urease activity by $89.5 \%$ of the strains. Acid from mannose, maltose and mannitol was produced by $86.8 \%, 24.7 \%$ and $9 \%$ of Group II strains, respectively. Group III 
Table 1

Characteristics of staphyl ococcal strains examined in the present study

\begin{tabular}{|c|c|c|c|c|c|c|c|c|c|c|c|c|c|c|}
\hline \multirow[b]{2}{*}{ Species } & \multicolumn{14}{|c|}{ No. of positively reacting strains } \\
\hline & Group & $\begin{array}{l}\text { No.o } \\
\text { strain }\end{array}$ & $\mathrm{IDH}$ & HYA & LIP & PRO & PIG & PHO & URE & SUC & TRE & MAN & MAL & MIT \\
\hline S. hyicus & $\begin{array}{l}\mathbf{A} \\
\mathbf{B} \\
\mathbf{C}\end{array}$ & $\begin{array}{r}281 \\
187 \\
76\end{array}$ & $\begin{array}{r}281 \\
187 \\
76\end{array}$ & $\begin{array}{r}281 \\
187 \\
76\end{array}$ & $\begin{array}{r}281 \\
187 \\
76\end{array}$ & $\begin{array}{r}281 \\
0 \\
42\end{array}$ & $\begin{array}{l}0 \\
0 \\
0\end{array}$ & $\begin{array}{r}278 \\
175 \\
73\end{array}$ & $\begin{array}{r}219 \\
174 \\
5\end{array}$ & $\begin{array}{r}281 \\
187 \\
0\end{array}$ & $\begin{array}{r}281 \\
187 \\
0\end{array}$ & $\begin{array}{r}186 \\
130 \\
0\end{array}$ & $\begin{array}{r}72 \\
65 \\
0\end{array}$ & $\begin{array}{r}0 \\
11 \\
0\end{array}$ \\
\hline S. chromogenes & $\underset{\text { III }}{\text { II }}$ & $\begin{array}{r}66 \\
219 \\
37\end{array}$ & $\begin{array}{r}66 \\
219 \\
37\end{array}$ & $\begin{array}{l}0 \\
0 \\
0\end{array}$ & $\begin{array}{l}0 \\
0 \\
0\end{array}$ & $\begin{array}{r}66 \\
219 \\
37\end{array}$ & $\begin{array}{r}66 \\
0 \\
16\end{array}$ & $\begin{array}{r}62 \\
200 \\
14\end{array}$ & $\begin{array}{r}58 \\
196 \\
10\end{array}$ & $\begin{array}{r}66 \\
219 \\
0\end{array}$ & $\begin{array}{r}58 \\
219 \\
0\end{array}$ & $\begin{array}{r}45 \\
190 \\
0\end{array}$ & $\begin{array}{r}25 \\
54 \\
0\end{array}$ & $\begin{array}{r}12 \\
20 \\
0\end{array}$ \\
\hline $\begin{array}{l}\text { Unclassified } \\
\text { "X" strains }\end{array}$ & & 71 & 71 & 0 & 71 & 69 & 0 & 71 & 71 & 71 & 60 & 45 & 14 & 0 \\
\hline
\end{tabular}

Explanatory notes: IDH, inhibition of staphylococcal delta haemolysin; HYA, hyaluronidase; LIP, hydrolysis of Tween 80; PRO, proteolysis; PIG, pigment; PHO, phosphatase; URE, urease; SUC, sucrose; TRE, trehalose; MAN, mannose; MAL, maltose; MIT, mannitol.

including $37(11.5 \%)$ strains differed from the foregoing S. chromogenes groups by inactivity in carbohydrates. Pigment was produced by $43 \%$, phosphatase by $38 \%$ and urease by $27 \%$ of Group III strains, respectively.

Group "X" strains all inhibited staphylococcal delta haemolysin similarly to $S$. hyicus and $S$. chromogenes strains. All of them also hydrolysed Tween 80 similarly to $S$. hyicus but, like $S$. chromogenes, did not produce hyaluronidase. Most of them $(97 \%)$ were proteolytic but the intensity of their protolytic activity was comparable to that shown by $S$. hyicus proteolytic strains, never reaching the intensity shown by $S$. chromogenes strains. All Group "X" strains were achromogenic, but they showed phosphatase and urease activity and produced acid from sucrose. Acid from trehalose, mannose and maltose was produced by $84.5 \%$, $63.4 \%$ and $19.7 \%$ of Group " $\mathrm{X}$ " strains, respectively. No strain of this group produced acid from mannitol.

The results are summarized in Table 1.

\section{Discussion}

Only few writers have been concerned with systematic investigation of the characteristics of $S$. hyicus and $S$. chromogenes and their respective diagnostic value. But even before Kloos and Schleifer (1986) published their nowadays generally accepted identification scheme, attention had been drawn to the possibility that $S$. hyicus and its then known subspecies might be confused with $S$. aureus, $S$. intermedius, S. epidermidis, S. simulans, S. capitis and S. hominis as was discussed by us previously. More recently, this possibility has been considered repeatedly (Gahrn-Hansen et al. 1987; Geary et al. 1989). When identification of staphylococci is based merely on their fermentation activity, it is also not possible to exclude the confusion between $S$. hyicus and $S$. chromogenes. Table 2 shows comparison of our results with those reported by writers dealing with similar problems.

The results reported in the present study support our previous observations on the capability of $S$. hyicus and $S$. chromogenes to inhibit staphylococcal delta haemolysin. This capacity was also shown by all strains classified by us within 
Table 2

Results and data reported by other writers

\begin{tabular}{|c|c|c|c|c|c|c|c|c|c|c|c|c|c|c|}
\hline \multirow{2}{*}{ Species } & \multirow{2}{*}{$\begin{array}{c}\text { Author } \\
\text { Year of } \\
\text { publications }\end{array}$} & \multirow{2}{*}{$\begin{array}{l}\text { No. of } \\
\text { strains }\end{array}$} & \multicolumn{12}{|c|}{ Percentage of positively reacting strains } \\
\hline & & & IDH & HYA & LIP & PRO & PIG & PHO & URE & SUC & TRE & MAN & MAL & MIT \\
\hline \multirow{4}{*}{$\begin{array}{l}\stackrel{0}{5} \\
\stackrel{5}{5} \\
\dot{s}\end{array}$} & \multirow{4}{*}{\begin{tabular}{|c|} 
D. \\
(1985) \\
K. S. \\
(1986) \\
Z. P. \\
$(1986)$ \\
G. \\
(1987) \\
Our study
\end{tabular}} & & $\mathbf{n}$ & 98 & 100 & 100 & 0 & 100 & 96 & 100 & 86 & 100 & 0 & $\mathbf{0}$ \\
\hline & & $\mathbf{n}$ & $\mathbf{n}$ & 100 & 100 & 100 & 0 & 100 & 80 & 100 & 100 & 100 & 0 & 10 \\
\hline & & $\mathbf{n}$ & $\mathbf{n}$ & $\mathbf{n}$ & $\mathbf{n}$ & $\mathbf{n}$ & 0 & 100 & 94 & 100 & 92 & 100 & 10 & 10 \\
\hline & & $\begin{array}{r}10 \\
544\end{array}$ & $\begin{array}{l}\mathrm{n} \\
100\end{array}$ & $\begin{array}{l}\text { n } \\
100\end{array}$ & $\begin{array}{l}100 \\
100\end{array}$ & $\mathbf{n}_{59}$ & $\begin{array}{l}0 \\
0\end{array}$ & $\begin{array}{r}100 \\
97\end{array}$ & $\begin{array}{r}100 \\
73\end{array}$ & $\begin{array}{r}100 \\
86\end{array}$ & $\begin{array}{r}100 \\
86\end{array}$ & $\begin{array}{r}100 \\
58\end{array}$ & $\begin{array}{r}0 \\
26\end{array}$ & $\begin{array}{l}0 \\
2\end{array}$ \\
\hline \multirow{4}{*}{ 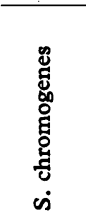 } & \multirow{4}{*}{$\begin{array}{c}\text { D. } \\
\text { (1985) } \\
\text { K. S. } \\
\text { (1986) } \\
\text { Z.P. } \\
\text { (1986) } \\
\text { G. } \\
\text { (1987) } \\
\text { Our study }\end{array}$} & 54 & $\mathbf{n}$ & $\mathbf{0}$ & $\mathbf{0}$ & 98 & 60 & 100 & 91 & 98 & 96 & 96 & 50 & 43 \\
\hline & & $\mathbf{n}$ & $\mathbf{n}$ & 0 & 0 & 100 & 90 & 100 & 90 & 100 & 100 & 100 & 50 & 58 \\
\hline & & $\mathbf{n}$ & $\mathbf{n}$ & $\mathbf{n}$ & $\mathbf{n}$ & $\mathbf{n}$ & 95 & 100 & 90 & 100 & 90 & 100 & 50 & 50 \\
\hline & & $\begin{array}{r}9 \\
322\end{array}$ & $\begin{array}{l}\text { n } \\
100\end{array}$ & $\begin{array}{l}\mathbf{n} \\
\mathbf{0}\end{array}$ & $\begin{array}{l}0 \\
0\end{array}$ & $\begin{array}{r}89 \\
100\end{array}$ & $\begin{array}{r}100 \\
25\end{array}$ & $\begin{array}{r}100 \\
87\end{array}$ & $\begin{array}{r}100 \\
82\end{array}$ & $\begin{array}{r}100 \\
89\end{array}$ & $\begin{array}{r}100 \\
86\end{array}$ & $\begin{array}{r}100 \\
73\end{array}$ & $\begin{array}{l}22 \\
24\end{array}$ & $\begin{array}{l}44 \\
10\end{array}$ \\
\hline Group & Our study & 71 & 100 & 0 & 100 & 97 & 0 & 100 & 100 & 100 & 85 & 63 & 20 & 0 \\
\hline
\end{tabular}

Explanatory notes: D., Devriese et al. (1985); K. S., Kloos and Schleifer (1986); Z. P., Zdražllek and Petrás (1986); G., Goodfellow et al. (1987); n, not specified; IDH, inhibition of staphylococcal delta haemolysin; HYA, hyaluronidase; LIP, hydrolysis of Tween 80; PRO, proteolysis; PIG, pigment; PHO, phosphatase; URE, urease; SUC, sucrose; TRE, trehalose; MAN, mannose; MAL, maltose; MIT, mannitol.

Group " $\mathrm{X}$ ". A similar, though less intense, effect can be observed in most strains of S. sciuri and S. lentus (Skalka 1990a, 1991) as well as in some micrococci (Iriu 1954; Skalka 1991). However, $S$. sciuri and $S$. lentus are resistant to novobiocin (Kloos and Schleifer 1986) and this characteristic itself differentiates them from the species considered in our study. Micrococci, on the other hand, have no phosphatase activity (Kocur 1986), which differentiates them, among other characteristics, from Group " $X$ " strains. No data for comparison with our results of the staphylococcal delta haemolysin inhi jition test are available; this characteristic was observed and described by us quite recently (Skalka 1990a, 1991).

Hyaluronidase is produced as a rule only by two species of the genus Staphylococcus, namely $S$. aureus and $S$. hyicus. Only quite exceptionally and then only in small quantities it can be also produced by some $S$. epidermidis strains (Kloos and Schleifer 1986) but these strains do not inhibit staphylococcal delta haemolysin; on the contrary, they generally produce it similarly to an overwhelming majority of $S$. aureus strains (Skalka 1990a, 1990b, 1991).

Our finding that Tween 80 was hydrolysed by all $S$. hyicus strains but by no $S$. chromogenes strains is in keeping with the data reported by most writers. This activity was also shown by Group " $X$ " strains. No explanation can be offered of the solitary finding of Tween 80 hydrolysis by $S$. chromogenes as reported by Goodfellow et al. (1987); as a matter of fact, this finding remained unexplained by the afore-mentioned writers themselves. Although Tween 80 hydrolysis may also be shown by some strains of $S$. aureus an $S$. intermedius, their activity in this respect is invariably less intense than that of $S$. hyicus and Group "X" strains. The delta haemolysin inhibition test, however, provides a reliable differentiation of the afore-mentioned groups of staphylococci. 
Proteolytic activity differentiating Group B strains from Group A and Group C strains of $S$. hyicus was markedly positive in all $S$. chromogenes strains. This characteristic is also shown by some $S$. aureus, $S$. intermedius and $S$. epidermidis strains (Kloos and Schleifer 1986; Skalka 1977, 1990b) that can be differentiated from $S$. hyicus and $S$. chromogenes by the delta haemolysin inhibition test. Also most $S$. sciuri strains are proteolytic but this species is novobiocin-resistant.

Our observations on the incapability of $S$. hyicus strains to produce pigment agree with those reported by other writers. In contrast to them, however, the proportion of pigmented $S$. chromogenes strains was lower than generally reported and the differing pigment production differentiated these strains into Groups I and II.

The results of the remaining tests used in our study did not differ substantially from those reported by other writers, particularly from the data recorded in the generally accepted classification of staphylococci (Kloos and Schleifer 1986).

Of interest, on the other hand, are our results obtained for $S$. hyicus Group C and $S$. chromogenes Group III strains which proved inactive in carbohydrates, particularly sucrose and trehalose. The proportions of these strains within $S$. hyicus and $S$. chromogenes were $14 \%$ and $11.5 \%$, respectively. This inactivity may give rise to diagnostic mistakes where $S$. hyicus and $S$. chromogenes strains are identified merely on the basis of their fermentation activity.

From our results it can be concluded that the most important characteristics for routine identification of $S$. hyicus are sensitivity to novobiocin, inhibition of staphylococcal delta haemolysin, production of hyaluronidase and hydrolysis of Tween 80, together with the absence of pigment production. Routine identification of $S$. chromogenes is possible on the basis of sensitivity to novobiocin, inhibition of staphylococcal delta haemolysin, intense proteolytic activity, absence of hyaluronidase production and inability to hydrolyse Tween 80 .

Group "X" strains were classified by us within the species $S$. hyicus in view of their hydrolysis of Tween 80 in spite of their negative hyaluronidase production.

\section{Diagnostický význam vlastností Staphylococcus hyicus a Staphylococcus chromogenes}

Sledoval se význam dvanácti vlastností pro určení Staphylococcus hyicus a Staphylococcus chromogenes, a to schopnost inhibovat stafylokokový hemolyzin delta, tvorba hyaluronidázy, hydrolýza Tween 80 , aktivita proteolytická, fosfatázová a ureázová, tvorba pigmentu, aerobní tvorba kyseliny v sacharóze, trehalóze, mannóze, maltóze a manitu. Použilo se 937 novobiocinsenzitivních stafylokokových kmenů, ze kterých náleželo 544 do druhu $S$. hyicus, 322 do druhu $S$. chromogenes a 71 se řadilo mezi oba druhy. Společnou vlastností všech použitých kmenů byla schopnost inhibovat stafylokokový delta hemolyzin. Všechny kmeny $S$. hyicus produkovaly hyaluronidázu a hydrolyzovaly Tween 80 . Na podkladě rozdílné proteolytické aktivity a utilizace karbohydrátů se rozdělily do tří nestejně početných skupin. Všechny kmeny $S$. chromogenes byly intenzívně proteolytické, netvořily hyaluronidázu a nehydrolyzovaly Tween 80 . Na podkladě různé produkce pigmentu a tvorby kyseliny $\mathrm{v}$ uhlohydrátech se rozdělily do tř́ různě početných skupin. 71 kmenů pưvodně nepřiřazených $\mathrm{k}$ žádnému $\mathrm{z}$ obou druhư se vyznaćovalo schopností hydrolyzovat Tween 80 . Pro tuto vlastnost byly tyto kmeny prriřazeny $\mathrm{k} S$. hyicus, vzdor jejich negativní produkci hyaluronidázy. 


\section{Диагностическое значение свойства Staphylococcus hyicus и Staphylococcus chromogenes}

Проводили исследования двенадцати свойств с целью определения Staphylococcus hyicus и Staphylococcus chromogenes, а именно способности торможения стафилококкового гемолиза дельта, образования гиалуронидазы, гидролиза Tween 80 , протеолитической активности, фосфатазной и уреазной активностей, образования пигмента, аэробного образования кислоты в сахарозе, маннозе, мальтозе и маните. Применили 937 новобиоцинсенситивных стафилококковых штаммов, из числа котоных 544 пнинадлежали S. hyicus, 322 - S. chromogenes и 71 К обоим видам. Совместное свойство всех применяемых штаммов сводилось к способности к ингибированию стафилококкового дельта-гемолизина. Все штаммы $S$. hyicus выделяли гиалуронидазу и гидролизовали Tween 80 . На основе разной протеолитической активности и утилизации карбогидратов их разделили на три, по численности неодинаковые группы. Все штаммы $S$. chromogenes отличались интенсивной протеолитичностью, не образовали гиалуронидазу и не гидролизовали Tween 80. На основе разной продукции пигмента и обравания кислоты в углеводах они делились на три разные по численности группы. 71 штамм, непринадлежавших первоначально ни к одному из двух видов, отличались способностью к гидролизу Tween 80. Упомянутые штаммы, исходя из приведенного свойства, были отнесены к $S$. hyicus, несмотря на их негативную продукцию гиалуронидазы.

\section{References}

DEVRIESE, L. A.-SCHLEIFER, K. H.-ADEGOKE, G. O.: Identification of coagulase-negative staphylococci from farm animals. J. Appl. Bacteriol., 58, 1985: 45-55

GAHRN-HANSEN, B.-HELTBERG, O.-ROSDAL, T. H.-SOGAARD, P.: Evaluation of a conventional routine method for identification of clinical isolates of coagulase-negative Staphylococcus and Micrococcus species. Comparison with API-Staph and API-Staph-Ident. Acta Pathol. Microbiol. Immunol. Scand. Sect. B, 95, 1987: 283-292

GEARY, C.-STEVENS, M. - SNEATH, P. H. A.-MITCHELL, C. J.: Construction of a database to identify Staphylococcus species. J. Clin. Pathol., 42, 1989: 298-294

GOODFELLOW, M.-HARWOOD, C. R.-NAHAIE, M. R.: Impact of plasmids and genetic change on the numerical classification of staphylococci. Zbl. Bakt. Hyg., A, 266, 1987: $60-85$

HÁJEK, V.-DEVRIESE, L. A. -MORDARSKI, M.-GOODFELLOW, M.-PULVERER, G. - VARALDO, P. E.: Elevation of Staphylococcus hyicus subsp. chromogenes (Devriese et al. 1978) to species status: Staphylococcus chromogenes (Devriese et al. 1978) comb. nov. Syst. Appl. Microbiol., 8, 1986: 169-173

KLOOS, W. E.-SCHLEIFER, K. H.: Genus IV. Staphylococcus Rosenbach 1884: p. 1013 to 1 035. In: SNEATH, P. H. A.-MAIR, N. S.-SHARPE, M. E.-HOLT, J. G. (ed.): Bergey's manual of systematic bacteriology. 1st ed. Vol. 2. Baltimore, London, Los Angeles, Sydney, Williams and Wilkins 1986: p. 965-1595

KOCUR, M.: Section 12. Gram-positive cocci. Genus I. Micrococcus Cohn 1872: p. $1004-1008$. In: SNEATH, P. H. A.-MAIR, N. S.-SHARPE, M. E.-HOLT, J. G. (ed.): Bergey's manual of systematic bacteriology. 1st ed. Vol. 2. Baltimore, London, Los Angeles, Sydney. Williams and Wilkins 1986: p. 965-1 595

LIU, P.: Inhibition of a staphylococcal hemolysin by a soluble substance produced by a nonhemolytic Micrococcus species. J. Bacteriol., 68, 1954: 718-723

SKALKA, B.: Diagnostics of coagulase-positive staphylococci with respect to the epizootiologic importance (orig. in Czech). Research report. Brno, 1977: $51 \mathrm{p}$.

SKALKA, B.: Isolation of Staphylococcus hyicus strains from healthy hosts and a diagnostic study of the strains (orig. in Czech). Veter. Med. (Praha), 33, 1988a: 607-616 
SKALKA, B.: Hemolytic activity of Staphylococcus hyicus and Staphylococcus chromogenes. Acta vet. Brno, 57, 1988b: $3-11$

SKALKA, B.: Hemolytic interactions of some gram-positive bacteria and their importance (orig. in Czech). Dissertation. Brno, 1990a, 204 p.

SKALKA, B.: Staphylococcal species isolated from healthy farm and free-living animals (orig. in Czech). Research report. Brno, 1990b: 48 p.

SKALKA, B.: Antagonistic effect of Staphylococcus hyicus and Staphylococcus chromogenes exhibited on staphylococaal delta hemolysin. Acta vet. Brno, 60, 1991: 61-69

ZDRAŽ́fLEK, J.-PETRÁŚ, P.: Genus Staphylococcus and Genus Micrococcus. p. 92-103. In: Anonym.: Classification of bacteria 1986. Praha, 1986: $134 \mathrm{p}$. 